University of South Carolina

Scholar Commons

2-1999

\title{
Law and Politics in Judicial Oversight of Federal Administrative Agencies
}

Martha Anne Humphries

Donald R. Songer

University of South Carolina - Columbia, dsonger@sc.edu

Follow this and additional works at: https://scholarcommons.sc.edu/poli_facpub

Part of the Law Commons, and the Political Science Commons

\section{Publication Info}

Published in Journal of Politics, Volume 61, Issue 1, 1999, pages 207-220.

http://www.journalofpolitics.org/

(C) 1999 by Cambridge University Press for the Southern Political Science Association

This Article is brought to you by the Political Science, Department of at Scholar Commons. It has been accepted for inclusion in Faculty Publications by an authorized administrator of Scholar Commons. For more information, please contact digres@mailbox.sc.edu. 


\title{
Law and Politics in Judicial Oversight of Federal Administrative Agencies
}

\author{
Martha Anne Humphries \\ Donald R. Songer \\ University of South Carolina
}

\begin{abstract}
Administrative agencies play a substantial role in the formulation and implementation of national policy. Central to this role is their exercise of discretion. A normative consensus exists that such discretion should be constrained by administrative deference to the rule of law. The courts of appeals are expected to insure that such discretion is constrained. The analysis reported below examines how effectively they fulfill that expectation. The findings suggest that agency success is related to political considerations, with agencies being successful when their decisions are consistent with the policy preferences of the judges. However, variables that captured elements of the legal model were also related to success. Taken together, it appears that the appeals courts respond to both legal concerns and political preferences. Thus, the courts appear to fulfill the expectation that they will constrain the worst abuses of discretion by imposing the rule of law.
\end{abstract}

$\mathbf{F}$ or decades students of politics in the United States have recognized that administrative agencies are important political actors that play a substantial role in the formulation as well as the implementation of national policy. As Peters (1989) notes, federal administrative agencies are "major formulators" of policy. Central to their role as policymakers is the extensive discretion exercised by administrative agencies (Horowitz 1994). While there is widespread acceptance of the necessity for administrative discretion, a normative consensus exists that such discretion should be constrained by administrative deference to the policy preferences of the president and Congress in addition to the substantive and procedural requirements of the rule of law. It is well known, however, that neither subservience to political superiors nor fidelity to the rule of law can be assumed to characterize all administrative action. Anecdotal evidence abounds of the abuse of discretion that results in the interjection of personal favoritism or political bias into administrative decisions. "Discretion has its dark side . . . [it] enables and even invites officials to overreach, to discriminate invidiously, to subordinate public interests to private ones . . . and to tyrannize over the citizenry" (Schuck 1994, 155). As a result, control of administrative discretion has been a "central problem" for decades of both theorists and practitioners of politics in the United States (Horowitz 1994). 
This concern has led to substantial agreement that there must be some legal restraints on the exercise of administrative discretion (Peters 1989). The "traditional form" of such attempts to provide legal control on administrative discretion "has been review by more or less independent tribunals of various kinds, principally generalist article III courts" (Schuck 1994, 156). In this context, judicial review is seen as a "check on lawlessness, a check on administrative agents making choices based on convenient personal or political preferences without substantial concern for matters of inconvenient principle" (Robinson 1991, 181).

A corollary of the expectation that courts will implement a legal check on the abuse of discretion by agencies is the assumption that courts, especially the federal appellate courts, will faithfully apply the law rather than their own political attitudes when they review agency decisions. Otherwise, instead of a check that imposes the rule of law, judicial review will merely result in the substitution of the private preferences of one set of actors for those of another. The present study explores whether review of agency decisions by the United States Courts of Appeals is in fact grounded in the rule of law, or is primarily a reflection of the policy preferences of the judges.

The courts of appeals have traditionally played a central role in the judicial review of agency decisions. This traditional appeals court role of supervising administrative agencies has steadily grown in importance over the last several decades in response to several environmental changes. First, their traditional role of supervising federal regulatory agencies has grown in importance as federal regulation of the economy has become more pervasive. Moreover, as the number of administrative appeals adjudicated in the circuit courts has increased dramatically, the number of cases of all types heard by the Supreme Court has remained flat (or even slightly declined). Thus, the objective probability that the Supreme Court will review an administrative law decision of the courts of appeals has declined sharply. As a result, the courts of appeals have become the final arbiter in practice for the overwhelming majority of challenges to the decisions of federal administrative agencies (Songer 1991). Therefore, if there is to be any legal check on abuse of discretion by administrative agencies, the courts of appeals are likely to have both the first and the final word in the judicial arena.

\section{Existing Research on Administrative Agencies before the Court}

Given the appeals courts' significant role in overseeing administrative agencies, it is surprising to find very little research on this topic. Studies abound on administrative agencies before the Supreme Court, yet similar studies cannot be found on the courts of appeals.

Empirical studies of federal administrative agencies before the Supreme Court, dating back as far as 50 years, show that agencies are one of the most successful litigants with average success rates of at least 70 percent (Canon and 
Giles 1972; Crowley 1987; Handberg 1979; Pritchett 1948; Sheehan 1990, 1992; Tanenhaus 1960). Some commentators suggest that one key to the success of agencies in court has been the Administrative Procedure Act (Tanenhaus 1960). The Administrative Procedure Act (APA) established the "substantial evidence doctrine," which mandates that the courts defer to the agency's assessment of fact provided there is substantial evidence to support their evaluation (Robinson 1991). These findings suggest that something of a paradox exists: courts are expected to be a primary line of defense against the abuse of agency discretion, yet they also are expected to give substantial deference to the exercise of such discretion. The "arbitrary and capricious test" and substantial evidence doctrine that form the basis of this deference "were built on a fundamental acceptance of the agency as expert, the notion that the agency was the arbiter of an objective, value-free technical rationality" (Horowitz 1994, 139).

The legal model of court decision making in agency cases suggests that courts are primarily concerned with clear precedent and an agency's adherence to procedural rules rather than with the substantive policies produced by the agency (Crowley 1987; Sheehan 1990). Under a long string of precedents, legal principles like the substantial evidence doctrine and the arbitrary and capricious test suggest considerable judicial deference to agency decisions, especially in their application of statutes to complex factual situations. Such unbiased treatment should lead to comparable levels of support among all the agencies, regardless of the agency's political orientation. However, this hypothesis has not been supported in the literature. In a study of administrative agencies' success rates before the Supreme Court from 1957 to 1968, Canon and Giles (1972) found the court was more supportive of decisions made by certain agencies than by others. The authors found that differences in agencies' substantive policies and goals appeared to play a role in determining the Court's support of the agencies. "In other words, variance in the Court's willingness to support an agency as a recurring litigant stems largely from the justices' attitudes toward the agency's substantive policies rather than its procedural behavior" (Canon and Giles 1972, 190).

Building on Canon and Giles's findings, researchers began attempting to explain why the differences in support of agencies existed. Donald W. Crowley began this endeavor by dividing the agencies into two categories: "old style" economic agencies and "new style" social agencies (1987). He hypothesized that the Supreme Court would support economic agencies at higher rates than social agencies partially due to the ideological battles existing in social regulation legislation and implementation. Crowley found the Court did support economic agencies more frequently than social agencies, suggesting that it was the justices' policy values rather than legal concerns that determined an agency's success in court.

In contrast to these studies, some support for a legal rather than an attitudinal model of decision making was discovered by Sheehan (1992), who hypothesized that a flaw in the past studies was the almost exclusive emphasis on independent 
regulatory agencies while virtually ignoring the executive agencies. He argued that an implication of the legal model was that independent regulatory agencies would receive greater deference from the Court because they were somewhat more insulated from the political influence of the executive branch and their own procedures followed a quasi-judicial format. His research found that the executive-type agencies fell under much stricter scrutiny than the independenttype agencies. As hypothesized, the Court was more willing to defer to the independent rather than the executive agencies (Sheehan 1992). But support for the notion that judicial attitudes rather than legal principles determined court review of agency decisions was enhanced when researchers analyzed whether the directionality of an agency's decision had an impact on the outcome of the case. Both Crowley (1987) and Sheehan (1990) found the ideological direction of the agency's decisions to have a significant influence on the level of deference granted by the Court to the agency. The researchers found that liberal and conservative judges both tended to shift their support for a particular agency based on the ideological direction of the agency's decision. Similarly, in a study of the Burger Court from 1969 to 1977, Spaeth and Teger (1982) found that justices were more likely to defer to probusiness or antilabor decisions of the agencies than prolabor or antibusiness decisions. These results reinforced the view that the ideological directionality of the agency's decision is influential in explaining the Supreme Court's differential treatment of administrative agencies (Spaeth and Teger 1982).

In summary, the high rate of success of agencies in the Supreme Court has been well documented, but we know less about the rate of success of agencies in the courts of appeals. In an examination of the effect of litigation resources on the success of appellants in the courts of appeals, Songer and Sheehan (1992) found that the federal government, a category including but not limited to administrative agencies, had the highest rate of success. A study by Sheehan and McWilliams (1992) on the circuit courts for 1979, 1983, and 1987 found that agencies were less successful than in the Supreme Court, and that there was no substantial difference in success rates between the executive and independent agencies. In Willison's (1986) study of the D.C. circuit from 1981 to 1984, he finds strong support for agencies, although there is considerable variance across the agencies and judges. He finds that some of the variance is accounted for by the political environment of the agency and the background characteristics of the judges, specifically their party affiliation.

Aside from the exceptions noted above, the research concerning administrative agencies in the federal courts focuses almost exclusively on the Supreme Court. In addition, the literature suggests that the legal model does not explain the success of agencies in court. Instead, the attitudes of the justices and their concern with the policy consequences of agency decisions appear to take precedence over the expectation that the courts will use law to constrain the discretion of administrative agencies. 


\section{A Model of Appeals Court Review of Agency Decisions}

Given the paucity of systematic analysis of judicial review of agency decisions in the courts of appeals, there is reason to question whether one should assume that the conclusions based on Supreme Court studies apply with equal force to appeals court review. There are several reasons to suspect that the conclusion that the legal model is irrelevant may not be applicable. First, in other areas of the law (e.g., civil liberties and criminal procedure) there is evidence that in the courts of appeals precedent has greater impact and that the attitudes of the judges are of less significance than in the Supreme Court (Howard 1981; Richardson and Vines 1970; Songer 1982; Songer and Haire 1992; Songer, Segal, and Cameron 1994). Moreover, none of the examinations of judicial review of administrative decisions directly tested for influences from the legal model. Instead, in each of the studies it was inferred that the law did not matter because evidence was uncovered that the policy preferences of the justices were strongly related to the patterns of support for the agencies. That is, the studies of Supreme Court review of agency decisions generally failed to investigate the possibility of the joint influence of the legal model and judicial attitudes on decisions. Finally, the studies of agency review in the Supreme Court generally failed to control for the possibility that the attitudes of the justices would have differential effects in relation to different types of issues. The model of judicial review described below is designed to test for the possibility of the joint influence of the legal model and judicial preferences on the likelihood that agency decisions will be overturned by the courts of appeals under controls for the types of issues present in each case.

The test of the prediction derived from the earlier studies (Crowley 1987; Sheehan 1992; Spaeth and Teger 1982) that agency success in the Supreme Court was primarily a function of the policy preferences of the justices rather than any influences associated with the legal model is straightforward. If a similar political model explains agency success in the courts of appeals, then agencies should be successful when the policy direction of their decision is congruent with the policy preferences of the majority of the reviewing court. To operationalize this test, one must create a measure of the ideological direction of the agency's decision and the ideological preferences of each court panel. To define the directionality of the agency's decision, we followed the definitions of "liberal" and "conservative" most commonly used in empirical analyses of lower federal courts. Specifically, to create the variable Agency Direction we employed the definitions used by Carp and Rowland (1983) ${ }^{1}$ in their analysis of federal district decisions (e.g., a liberal decision was defined as one that supported the government in a challenge to the authority of the government to regulate the economy, that favored unions in conflicts against management, that supported

\footnotetext{
${ }^{1}$ These definitions are essentially the same as those used in most studies using the Supreme Court Data Base, Harold J. Spaeth (Principal Investigator), and are consistent with the definitions of liberal and conservative adopted by Crowley (1987) and Sheehan (1990, 1992).
} 
greater protection for the environment or consumers in environmental and consumer protection cases, or supported the person claiming a violation of constitutionally protected rights in a civil liberties case).

Unfortunately, we do not have direct, independent measures of the ideology of the hundreds of appeals court and district court judges who served on the panels of the courts of appeals that have reviewed agency decisions over the 20-year period included in this analysis. Nor is it feasible to obtain them. We therefore adopted an inferential measure of the ideology of each judge based on a linear combination created by the logistic regression coefficients from a model of judges' votes in nonconsensual cases. The dependent variable in this model was judges' votes in economic cases with $1=$ liberal vote and $0=$ conservative vote. The characteristics of judges that best explained the likelihood of a liberal vote were the ideology of the appointing president and the region of appointment (a North/-South dichotomy) ${ }^{2}$ Specifically, for appointing president we adopted the measure created by Tate and Handberg (1991) that scored judges appointed by liberal ideologically oriented presidents as 1 , those appointed by conservative ideologically oriented presidents as -1 , and those appointed by presidents that were not strongly ideological in their appointment strategies as 0 . Using the coefficients from this model resulted in the following equation for a measure of judge ideology:

$$
\text { Judge Ideology }=.225 * \text { Appointing President }+.356 * \text { Region }
$$

A measure of the ideology of the appeals court panel that reviewed the agency decision (labeled Panel Ideology) was created by computing the mean judge ideology score of all the judges (including district judges and appeals judges on senior status) who participated in the panel's decision. To test the predictions of the political model, we then computed the multiplicative term Panel Ideology * Agency Direction. If the political model of decision making is correct, this interactive term should be positively related to the probability of agency success in the courts of appeals.

A major impediment to empirical attempts to assess the impact of the legal model on appellate court decision making has been the difficulty of identifying objective indicators that capture the effects of law and precedent. While a central feature of the legal model is the expectation that judges should follow precedent, judgments about whether a court in a particular case actually followed precedent tend to be highly subjective, typically raising serious questions about their validity and reliability. In this study, the implications of legal precedents are examined

\footnotetext{
${ }^{2}$ We tested other measures of state and/or regional influence, specifically including the ADA scores of the home state senators at the time of appointment; the Wright, Erikson, and McIver measure of state ideology; and the Berry et al. (1998) dynamic measure of state ideology (for both the time of appointment and the time of the judicial decision). However, none of these measures were statistically significant, nor did they improve the performance of the overall model to a statistically significant degree.
} 
to identify the nature of the legal challenges to agency action that may be expected to result in the greatest probability of success for the challengers. Under a political model, like the realist school of jurisprudence, or the modern-day Attitudinal Model, the legal basis of the challenge to an agency's decision should have no impact on the likelihood that the agency will be supported, since the Attitudinal Model views legal doctrine as "mere rationalization" (Segal and Spaeth 1993).

As noted above, the justification for judicial deference to agency discretion has traditionally been rooted in the view of agencies as the possessors of technical expertise that is superior to the expertise of the courts. As outlined in the APA, and more specifically in the substantial evidence doctrine, judicial deference toward agencies should be exercised if there is substantial evidence to support the agency's assessment of facts. To test whether circuit judges were bound by this legal doctrine, we created a variable Substantial Evidence, which was coded " 1 " if the agency decision was challenged under the substantial evidence doctrine, and " 0 " if the doctrine was not applied. The legal model leads to the expectation that because of the expected judicial deference in such cases, agency success rates should be higher in such cases than in cases based on the interpretation of statutes.

Alternatively, it is reasonable to believe that judges will be least impressed by an agency claim for deference in cases that involve interpretation of a federal statute. Interpretation of federal statutes are at the heart of the judicial role. Thus, the legal model leads to the prediction that for cases in which the variable Federal Law is coded " 1 " to indicate the presence of an issue of interpretation of a federal statute, agencies will have lower rates of success than they will in cases in which the variable is coded " 0 " to indicate the absence of such an issue.

The two variables described above reflect enduring features of the legal model that should have affected appeals court decisions throughout the period studied if there is validity to the legal model. But to adequately capture the effects of the legal model, one must also model the dynamic element of changing precedent. Most important for a study of the courts of appeals are the changing precedents announced by the Supreme Court. Unfortunately, no quantifiable direct measure of changing precedent is both available and reliable. However, a rough indicator of changing precedent in administrative agency cases may be obtained from calculating the percentage of liberal and conservative agency rulings that were affirmed by the Supreme Court. We looked at Supreme Court policymaking in cases reviewing agency decisions. We ran the analysis separately for four periods, divided by changes in natural courts: late Warren Court (1962-68 terms), early Burger Court (1969-75 terms), late Burger Court (1976-85 terms), and the Rehnquist Court (to the end of 1989 term). For each period, we calculated two measures: the percentage of liberal agency decisions that were supported by the Court and the percentage of conservative decisions supported by the Court. The measure of Supreme Court precedent was conceptualized as the probability that 
a given agency decision at issue in the courts of appeals would be supported if the appeals court decision was reviewed by the Court. For example, if the appeals court was reviewing a conservative agency decision in 1986, the percentage of conservative agency decisions supported by the Rehnquist Court was our measure of Supreme Court precedent.

In summary, three variables were created to capture elements of the legal model, and predictions were made about the relationships between each of these variables and agency success. All of these measures are relatively rough indicators of legal effects, so even their combined effect probably underestimates the impact of law and precedent on courts' decisions. Nevertheless, by providing predictions of the relationships that could be expected to exist if judges in fact were constrained by precedent, etc., we may obtain at least a general assessment of the validity of the legal model. To these measures of the effect of the legal model, we added one measure of the propensity of judges to support agency decisions that advanced their policy preferences.

\section{Data and Methods}

The focus of the present study is the success rates of administrative agencies in the U.S. Courts of Appeals from 1969 to $1988 .^{3}$ Existing research on the Supreme Court suggests that administrative agencies should be one of the more successful litigants appearing before the court. The starting point for analysis is the computation of the overall success rates of the agencies for this 20 -year period.

Once the success rate has been determined, an attempt will be made to test the model for predicting agency success described above. The dependent variable for this analysis is agency success, which takes the value 1 if the agency position is supported by the court and 0 if the agency decision is reversed. Mixed decisions, where the agency was supported in part and reversed in part, were excluded from analysis.

Because least squares regression is inappropriate when the dependent variable is dichotomous (Aldrich and Nelson 1984), as in the present analysis, the parameters of the models were estimated by logistic regression, a maximum-likelihood estimation technique. This method produces estimates for the parameters of a model's independent variables in terms of the contribution each makes to the probability that the dependent variable falls into one of the designated categories

\footnotetext{
${ }^{3}$ Our analysis begins at the beginning of the "judicialization of the administrative process" (O'Brien 1986, 33) and ends at the end of the Appeals Court database. O'Brien (1986) argues that beginning in the early 1970s there was diminished judicial deference to agency discretion and expertise, and greater judicial policymaking. Melnick (1983) agrees, noting that the early 1970s ushered in a "new era in administrative law" characterized by more critical judicial overview of agency action (9). Beginning our analysis in 1969 allows us to test if deference to the agencies and adherence to the law was diminished by attention to policy preferences of judges, as proponents of a political model would suggest.
} 
(e.g., an agency was supported or not supported). For each independent variable, a maximum-likelihood estimate (MLE) is calculated along with its standard error (SE). The MLEs represent the change in the logistic function that results from a one-unit change in the independent variable.

The data for this analysis comes from the Appeals Court Data Base. ${ }^{4}$ From the database, which includes a stratified random sample of all published decisions of the Courts of Appeals from 1925 to 1988, all cases from the last 20 years of the database (1969-88) where a federal agency is a party, as either an appellant or a respondent, were examined. The data on the appeals court judges and their party affiliations comes from the Auburn judge database. ${ }^{5}$

\section{Agency Success in the Courts of Appeals}

Examination of Table 1 indicates that federal agencies are successful in the courts of appeals. Overall, agencies won slightly over three-fifths of the cases that reached the courts. Since many of their opponents were repeat players with substantial resources, this success rate is significant. Nevertheless, the rate of success of agencies in the courts of appeals appears to be substantially lower than the success other studies have reported them achieving in the Supreme Court, and is somewhat lower than the success rate for agencies in the D.C. circuit reported by Willison (1986). ${ }^{6}$

Having established that agencies are generally successful, we next turn to our model of the factors that contribute to that success. The results are presented in Table 2. The coefficients in Table 2 show the change in the log of the odds ratio

TABLE 1

Success Rate of Federal Administrative Agencies in the U.S. Courts of Appeals, 1969-1988

$\begin{array}{rlrl}\text { Success of agency when appearing as respondent } & = & 62.6 \% & (\mathrm{~N}=559) \\ \text { Success of agency when appearing as appellant } & = & \begin{aligned} 43.4 \% \\ (\mathrm{~N}=175)\end{aligned} \\ \text { Overall success rate }= & 58.0 \% & (\mathrm{~N}=734)\end{array}$

\footnotetext{
${ }^{4}$ The United States Courts of Appeals Data Base, Donald R. Songer (Principal Investigator), NSF\# SES-8912678.

${ }^{5}$ The United States Courts of Appeals Judge Data Base, Gary Zuk, Deborah J. Barrow, and Gerard S. Gryski (Co-Principal Investigators), NSF\# SBR-93-11999.

${ }^{6}$ This aggregate success rate is also substantially lower than those found by Unah (1997) for the International Trade Commission and the Department of Commerce in the Federal Circuit. When we examined the success rates of agencies individually, we found significant variation among agencies. Several agencies had success rates equal to or greater than the aggregate success rate in the Supreme Court, whereas others, like the NLRB, lost more than half the cases in which they appeared. Further research may explore the agencies individually to determine if there are idiosyncratic factors influencing success.
} 
TABLE 2

A Logistic Regression Model of Federal Agency Success in the U.S. Courts of Appeals, 1969-1988

\begin{tabular}{lccr}
\hline Independent Variables & MLE & SE & Impact $^{\mathrm{a}}$ \\
\hline Panel Judge Ideology & $-2.000^{* *}$ & 0.623 & -.381 \\
Agency Direction & $0.539^{* *}$ & 0.174 & .132 \\
Panel Ideology * Agency Direction & $2.973^{* *}$ & 0.839 & .452 \\
Supreme Court Precedent & $0.025^{*}$ & 0.011 & .007 \\
Substantial Evidence & $0.469^{* *}$ & 0.176 & .115 \\
Federal Law & $-0.301^{*}$ & 0.164 & -0.75 \\
Intercept & -0.804 & 0.435 &
\end{tabular}

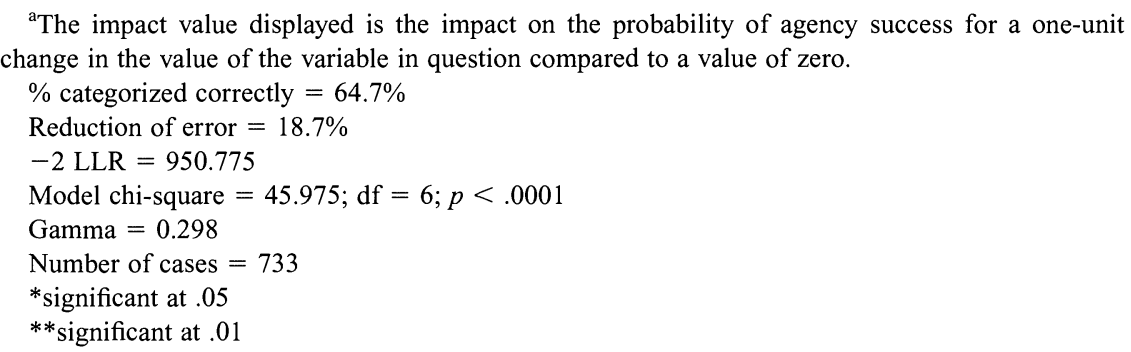

for a decision by the court to support the position of the agency, given the presence of each of the other independent variables. Since this coefficient is not readily interpretable, we provide under the column labeled "impact" the estimated increase or decrease in the probability of a supportive decision when the variable in question is present. This estimate assumes that a supportive decision otherwise has a 50-50 chance of being made. ${ }^{7}$

At first glance, the data in Table 2 appear to suggest that the effect of judicial preferences on the chances for agency success in the courts of appeals mirror the findings of Crowley (1987) and Sheehan $(1990,1992)$ in the Supreme Court. Panels of liberal judges are much more likely to uphold liberal than conservative agency decisions and conservative judges favor conservative decisions. For example, for a liberal agency decision that had a $50 \%$ chance of being supported by a politically neutral panel of judges, there would be an estimated $88 \%$ chance that a panel with three judges appointed by a liberal, ideologically conscious president (e.g., Johnson) would support the agency. On the other hand, the same decision would have only a $12 \%$ chance of support if the judges were appointed by a conservative president like Reagan. These results suggest that the policy preferences of the judges are strongly related to the probability that the agency will win in court.

\footnotetext{
${ }^{7}$ At any other value, the estimated impact depends on whether the coefficient is positive or negative. Only at .50 is it symmetrical and thus nonarbitrary.
} 
The studies of agency success in the Supreme Court assumed that a finding that the probability of agency success was strongly correlated with the congruence (or lack of congruence) between the policy direction of the agency decision and the policy preferences of the justices meant that the legal model was irrelevant. In contrast, our model of appeals court decisions attempted to measure more directly whether legal variables mattered. Three variables that tapped various aspects of the legal model were included in the analysis. First, the legal model led to the prediction that the appeals court would be responsive to trends in Supreme Court policy. Specifically, we hypothesized that the probability of success in the Supreme Court for the agency, based upon the directionality of the agency's decision, would influence the voting behavior of the circuit judges. The variable Supreme Court Precedent was in the correct direction and statistically significant, providing support for our hypothesis. That is, as the Supreme Court became more conservative, the probability that the courts of appeals would support a conservative agency decision increased. For example, using the value of the impact measure reported in Table 2, we can predict that a conservative agency decision that had a $50 \%$ chance of being supported by the courts of appeals in 1970 would have a $66 \%$ chance of support by the same panel of judges in 1980 when the Supreme Court had become considerably more conservative.

The second prediction derived from the legal model was that agencies would have a greater chance of success when the appeals court applied the substantial evidence doctrine. The data in Table 2 indicate that the expectation of success in substantial evidence cases received strong support. An agency decision that would otherwise have a $50 \%$ chance of support would have a $61 \%$ chance of support if the substantial evidence doctrine was applied. In addition, the expectation that agencies would be less successful in cases raising challenges to a federal law was also confirmed in the model.

In summary, the predictions that were derived from the legal model received substantial support in the data. All of the relationships were in the predicted direction, were statistically significant, and the magnitude of the effects appears to be substantial.

\section{Conclusions}

The data in this study demonstrate that while administrative agencies do not enjoy as high a level of success in the courts of appeals as in the Supreme Court, they are still successful in over half the cases in which they appear.

The findings suggest that agency success in the appeals courts, as in the Supreme Court, is strongly related to political considerations. Judges at both levels are much more likely to uphold the exercise of discretion by the agency when the policy implications of that exercise are consistent with the policy preferences of the judges. However, it would be a mistake to view judicial review of agency decisions as a purely political exercise. The judges do not appear to simply 
substitute their own policy preferences for those of the administrators without regard for law. Variables that captured elements of the legal model were also related to judicial decisions to a statistically significant degree. Taken together, the evidence suggests that the appeals courts appear to respond to both legal concerns and political preferences. Thus, while it would be naive to believe that politics is irrelevant in judicial review of agencies, it appears that the courts do fulfill, at least in part, the normative expectations that they will constrain the worst abuses of discretion by administrators by imposing the rule of law. We believe that the most reasonable explanation of the findings is that the courts of appeals are staffed with judges who are policy oriented and attempt to bring agency policy into line with their own policy preferences but feel constrained to pursue their preferences within limits set by the law. Put slightly differently, the courts are responsive to the law even though the law does not always dictate an unambiguous resolution of every case. As a result, when Supreme Court precedent becomes more conservative, the courts of appeals adjust their own patterns of decision making. Liberal panels still attempt to find ways to achieve liberal outcomes, but will feel their discretion to achieve those ends to be more limited. Thus, as Supreme Court precedent shifts in a conservative direction, it appears that the decision patterns of both conservative and liberal appeals court panels will become more conservative, even though the probability of a liberal decision will remain greater if the panel is composed of liberal judges.

Since several studies noted above suggest that in the Supreme Court, the nature of the agency may affect the probability of agency success in the courts, we ran additional models controlling for agency type (both economic/social and independent/executive). We found that these control variables did not have a significant impact on the strength of our existing variables. Furthermore, the model was not significantly improved by the addition of these variables, and neither variable was statistically significant. We think this is an interesting sidelight of our model since studies on the Supreme Court found agency types to be significant. When we ran a model with only the agency type variables, we found that the economic/social dichotomy was significant, but the independent/executive was not. These findings suggest that once controls are introduced for both legal constraints and the policy implications of the decisions, agency type per se appears to be irrelevant.

The measures employed of both political preferences and legal constraints are admittedly rough. The most likely result of the use of such rough indicators is an increase in random error, and this may account for the substantial amount of unexplained variance in the model. Future research should strive to develop more precise indicators. In particular, we were only able to develop indirect indicators of legal effects. Instead of directly measuring the degree to which precedent in a given case supported a decision to uphold agency discretion, we were only able to make predictions from rough indicators of issues about the pattern of results that could be expected if the legal model were valid. The support of these pre- 
dictions certainly is consistent with the hypothesis that law matters, but future research can hopefully produce more direct measures of the impact of precedent.

\section{Manuscript submitted 13 August 1997 \\ Final manuscript received 13 May 1998}

\section{References}

Aldrich, John H., and Forrest Nelson. 1984. Linear Probability, Logit, and Probit Models. Beverly Hills: Sage Publications.

$\rightarrow$ Berry, William D., Evan J. Ringquist, Richard C. Fording , and Richard L. Hanson. 1998. "Measuring Citizen and Government Ideology in American States, 1960-1993." American Journal of Political Science 42 (February): 327-48.

$\rightarrow$ Canon, Bradley C., and Michael Giles. 1972. "Recurring Litigants: Federal Agencies before the Supreme Court." Western Political Quarterly 25 (June): 183-91.

Carp, Robert A., and C. K. Rowland. 1983. Policymaking and Politics in the Federal District Courts. Knoxville: University of Tennessee Press.

$\rightarrow$ Crowley, Donald W. 1987. "Judicial Review of Administrative Agencies: Does the Type of Agency Matter?" Western Political Quarterly 31 (June): 265-83.

Handberg, Roger. 1979. "The Supreme Court and Administrative Agencies: 1965-1978." Journal of Contemporary Law 6 (Fall): 161-76.

Horowitz, Robert B. 1994. "Judicial Review of Regulatory Decisions: The Changing Criteria." Political Science Quarterly 109 (Spring): 133-69.

Howard, J. Woodford, Jr. 1981. Courts of Appeals in the Federal Judicial System: A Study of the Second, Fifth, and District of Columbia Circuits. Princeton: Princeton University Press.

Melnick, R. Shep. 1983. Regulation and the Courts: The Case of the Clean Air Act. Washington, DC: Brookings Institution.

Nowak, John E., and Ronald D. Rotunda. 1991. Constitutional Law. 4th ed. St. Paul: West Publishing Co.

O'Brien, David. 1986. "Administrative Discretion, Judicial Review, and Regulatory Politics." In $A d-$ ministrative Discretion and Public Policy Implementation. New York: Praeger.

Peters, B. Guy. 1989. The Politics of Bureaucracy. 3d ed. New York: Longman.

Pritchett, Herman. 1948. The Roosevelt Court: A Study in Judicial Politics and Values, 1937-1947. New York: Macmillan.

Richardson, Richard J., and Kenneth N. Vines. 1970. The Politics of Federal Courts. Boston: Little, Brown and Company.

Robinson, Glen O. 1991. American Bureaucracy: Public Choice and Public Law. Ann Arbor: University of Michigan Press.

Schuck, Peter H. 1994. Foundations of Administrative Law. New York: Oxford University Press.

Segal, Jeffrey A., and Harold J. Spaeth. 1993. The Supreme Court and the Attitudinal Model. Cambridge: Cambridge University Press.

$\rightarrow$ Sheehan, Reginald S. 1990. "Administrative Agencies and the Court: A Reexamination of the Impact of Agency Type on Decisional Outcomes." Western Political Quarterly 43 (December): 875-85.

Sheehan, Reginald S. 1992. "Federal Agencies and the Supreme Court: An Analysis of Litigation Outcomes, 1953-1988." American Politics Quarterly 20 (October): 478-500.

Sheehan, Reginald S., and Nancy L. McWilliams. 1992. "Federal Agencies in the United States Court of Appeals." Presented at the annual meeting of the Southern Political Science Association.

$\rightarrow$ Songer, Donald R. 1982. "Consensual and Nonconsensual Decisions in Unanimous Opinions of the United States Courts of Appeals." American Journal of Political Science 26 (May): 225-39. 
Songer, Donald R. 1991. "The Circuit Courts of Appeals." In The American Courts: A Critical Assessment, ed. Gates and Johnson, 35-59. Washington, DC: Congressional Quarterly Press.

$\rightarrow$ Songer, Donald R., and Susan Haire. 1992. "Integrating Alternative Approaches to the Study of Judicial Voting: Obscenity Cases in the U.S. Courts of Appeals." American Journal of Political Science 36 (November): 963-82.

$\rightarrow$ Songer, Donald R., Jeffrey A. Segal, and Charles A. Cameron. 1994. "The Hierarchy of Justice: Testing a Principal-Agent Model of Supreme Court-Circuit Court Interaction." American Journal of Political Science 38 (August): 673-96.

$\rightarrow$ Songer, Donald R., and Reginald S. Sheehan. 1992. "Who Wins on Appeal? Upperdogs and Underdogs in the United States Courts of Appeals." American Journal of Political Science 36 (February): 235-58.

Spaeth, Harold J., and Stuart Teger. 1982. “Activism and Restraint: A Cloak for the Justices' Policy Preferences." In Supreme Court Activism and Restraint, ed. Halpern and Lamb, 277-302. Lexington, MA: Lexington Books.

$\rightarrow$ Tanenhaus, Joseph. 1960. "Supreme Court Attitudes toward Federal Administrative Agencies." Journal of Politics 22 (August): 502-24.

$\rightarrow$ Tate, C. Neal, and Roger Handberg. 1991. "Time Binding and Theory Building in Personal Attribute Models of Supreme Court Voting Behavior, 1916-88." American Journal of Political Science 35 (May): 460-80.

$\rightarrow$ Unah, Isaac. 1997. "Specialized Courts of Appeals' Review of Bureaucratic Actions and the Politics of Protectionism.” Political Research Quarterly 50 (December): 851-78.

Willison, David H. 1986. "Judicial Review of Administrative Decisions: Agency Cases before the Courts of Appeals for the District of Columbia, 1981-1984." American Politics Quarterly 14 (October): $317-27$.

$\rightarrow$ Wright, Gerald C., Robert S. Erikson, and John P. McIver. 1987. "Public Opinion and Policy Liberalism in the American States.” American Journal of Political Science 31 (November): 981-99.

Martha Anne Humphries is a Ph.D. candidate at the University of South Carolina, Columbia, SC 29208.

Donald R. Songer is professor of political science, University of South Carolina, Columbia, SC 29208. 